\title{
Pengukuran Perilaku Ibu Menyusui dalam Melakukan Kunjungan Ke Klinik Laktasi
}

\author{
Agussanti Br Ginting \\ Sekolah Tinggi Ilmu Kesehatan Indonesia Maju \\ Alamat: Jl. Harapan No. 50 Lenteng Agung Jakarta Selatan 12610 \\ Telp. 021-78894043 Email: santiginting84@ gmail.com
}

\begin{abstract}
Abstrak
Klinik laktasi merupakan tempat ibu berkonsultasi dengan tenaga medis yang memiliki pengetahuan mengenai pemberian ASI. Tapi pada kenyataannya klinik ini belum dipergunakan maksimal oleh masyarakat.Tujuan umum penelitian ini adalah untuk mengetahui pengaruh langsung dan tidak langsung serta besaran Pengetahuan dan Sikap Ibu serta Dukungan Suami. Terhadap Perilaku ibu menyusui dalam melakukan kunjungan ke klinik laktasi Rumah Sakit Hermina Bekasi Tahun 2015. Metode penelitian ini menggunakan rancangan cross-sectional. Populasinya adalah ibu yang berkunjung pada bulan Maret 2015 sebanyak 45 orang. Besar sampel merupakan accidental sampling. Data yang dikumpulkan data primer dengan alat bantu kuesioner. Data diolah dan di analisis menggunakan program Statistik berbasis komputer yaitu SPSS dan PLS. Hasil penelitian 5 hubungan antar variabel berpengaruh signifikan secara positif dengan taraf $\alpha=5 \%(0,05=$ confidence $95 \%)$ dari sampel 45 orang pada model akhir yang dimodifikasi. Kesimpulannya Persentase pengaruh semua variabel terhadap perilaku dalam model ini sebesar $67,42 \%$, yang terdiri dari pengaruh langsung sebesar 57,40\% dan pengaruh tidak langsung sebesar 10,02\%. Disarankan agar Rumah Sakit Hermina Bekasi untuk lebih mempromosikan klinik laktasinya dan mengubah sikap ibu ke arah lebih positif agar ibu yang berkunjung semakin banyak.
\end{abstract}

Kata Kunci : Dukungan Suami, Pengetahuan, Perilaku, Sikap

\begin{abstract}
Lactation clinic is the place of a mother consult with medical workers have knowledge regarding the grant of breastfeeding. But in fact it has not be used by publik. Maximum common this study is to find the influence of the direct and indirect as well as the amount of the knowledge and attitudes support mother and husband. Against a nursing mother behavior in doing trips to the clinic lactation hermina hospital Bekasi the year 2015. Research method was used in the design of cross-sectional. The population was mother who is visiting in march 2015 as many as 45 people. Large sample of sampling is accidental. The data collected primary data with the tools the questionnaire. The data being processed and in analysis using statistics program computer-based namely SPSS and PLS. The results of research 5 the relations between variables significant positively with standard $\alpha=5 \%(0,05=$ confidence 95\%) of the sample 45 people on the model modified the end. In conclusion the percentage of the influence of all the variables against behavior in this model of 67,42\%, consisting of a direct influence of 57,40 \% and indirect effect of 10,02\%. Suggested that Hermina hospital Bekasi to further promote laktation clinic and change attitudes mother toward the more positive to mothers who visit more.
\end{abstract}

Keywords $\quad$ : Knowledge, Attitude, Husband Support, Behavior 


\section{Pendahuluan}

Angka Kematian Bayi (AKB) adalah jumlah kematian bayi dalam usia 28 hari pertama kehidupan per 1000 kelahiran hidup. Angka ini merupakan salah satu indikator derajat kesehatan bangsa. Tingginya angka kematian bayi ini dapat menjadi petunjuk bahwa pelayanan maternal dan neonatal kurang baik. ${ }^{1}$ Menurut laporan World Health Organization (WHO) pada tahun 2000 Angka Kematian Bayi (AKB) di dunia 54 per 1000 kelahiran hidup dan tahun 2006 menjadi 49 per 1000 kelahiran hidup. Menurut data dari Survei Demografi dan Kesehatan Indonesia (SDKI) tahun 2007 sebesar 34/1000 kelahiran hidup sedangkan angka Kematian balita (AKBAL) pada tahun 2007 sebesar 44/1000 kelahiran hidup. ${ }^{2}$ Berdasarkan hasil sementara Survei Penduduk Antar Sensus (SUPAS) tahun 2015, Angka Kematian Bayi (AKB) di Indonesia mencapai 22 per 1000 kelahiran hidup dan Angka Kematian Balita (AKBA) mencapai 26 per 1000 kelahiran hidup. ${ }^{3}$

Data DKI Jakarta Tahun 2010, jumlah AKB 4/1000 kelahiran hidup (Humas DinKes DKI Jakarta, 2010). Pada tahun 2012 AKB masih tergolong ada peningkatan yaitu 19/1000 kelahiran hidup. Salah satu upaya yang dilakukan pemerintah dalam membantu mengurangi $\mathrm{AKB}$ tertuang dalam Keputusan Menteri Kesehatan No.450/MENKES/SK/VI/SK/2004 tentang program pemberian air susu ibu (ASI) secara eksklusif. $^{4}$

Pemberikan air susu ibu secara eksklusif berperan menurunkan angka kematian bayi sampai enam persen, sehingga kaum perempuan diharuskan menyusui sejak anak dilahirkan sampai usia dua tahun. ASI menjadi salah satu hal yang penting dalam mendorong tumbuh kembang generasi yang sehat dan cerdas. ASI berperan dalam sistem pertahanan tubuh bayi untuk mencegah berbagai penyakit. Setiap tetes ASI juga mengandung mineral dan enzim untuk pencegahan penyakit dan antibody yang lebih efektif dibandingkan dengan

kandungan yang terdapat dalam susu formula, sehingga jika anak mendapatkan ASI bisa dihindarkan dari kematian yang seharusnya tidak perlu. Pemberian ASI bisa menurunkan persentase kematian hingga $13 \%$. Di
Indonesia, menurut data susenas (survey sosial ekonomi nasional) cakupan pemberian ASI eksklusif pada bayi sampai 6 bulan turun 28,6\% pada tahun 2007 menjadi 24,3\% pada tahun 2008. Hasil riset kesehatan dasar (Risdeskas) tahun 2010 menunjukan bahwa pemberian ASI eksklusif sampai usia 6 bulan di Indonesia masih rendah, yaitu hanya sebesar 15,3\%. Menurut data SDKI tahun 2012, persentase bayi yang mendapatkan ASI Eksklusif (untuk umur bayi dibawah 6 bulan) sebesar 41\%, ASI Eksklusif pada bayi umur 45 bulan sebesar $27 \%$, dan yang melanjutkan menyusui sampai anak umur 2 tahun sebesar 55\%. Dalam memberikan ASI eksklusif kepada bayi, tidak selamanya akan berjalan mulus. Kadang seorang ibu yang pertama kali menyusui akan mengalami beberapa kendala terkait dengan produksi ASI atau payudaranya. Beberapa masalah yang sering muncul saat menyusui adalah puting susu terbenam, puting lecet dan nyeri, saluran ASI tersumbat, radang payudara, produksi ASI kurang, penurunan suplai darah ke puting, payudara bengkak, produksi ASI berlebih. Perda No. 7 Tahun 2008 tentang Inisiasi Menyusu Dini dan ASI Eksklusif. Perda No. 7 Tahun 2008 secara garis besar berisi tentang IMD dan ASI Eksklusif, pemberian perlindungan untuk Ibu dan Bayi, tidak mengebiri Hak Ibu, penyediaan lingkungan yang mendukung disekitar Ibu (seperti keluarga, masyarakat dan institusi) serta prioritas tersedianya Ruang Laktasi di institusi, perkantoran pemerintah/swasta dan tempat-tempat layanan umum (TTU). Mengenai pelaksanaanya, pemerintah ternyata serius dalam memenuhi hak bayi, terbukti dengan diadakannya klinik laktasi serta ruang menyusui bagi ibu menyusui di rumah sakit milik pemerintah maupun swasta. Tapi memang sampai saat ini belum dimanfaatkan secara maksimal oleh masyarakat. Saat ini klinik laktasi ada di 21 kota di Indonesia dan juga hampir ditemukan di seluruh rumah sakit. $^{5}$

Berdasarkan indikator dan target upaya kesehatan cakupan klinik/pojok laktasi tahun 2014 sebesar 81. Kunjungan Ibu baru melahirkan pertama (kunjungan neonatal/KN1) sebesar $71,3 \%$ dan $\mathrm{KN}$ lengkap sebesar 39,3\%. Pada kenyataanya klinik laktasi masih belum dimanfaatkan dengan baik terbukti angka kunjungan dan pemberian ASI eksklusif masih rendah. ${ }^{6}$ 
Pengertian pengetahuan merupakan hasil dari tahu, dan ini terjadi setelah seseorang melakukan pengindraan terhadap suatu objek tertentu, yakni indra penglihatan, pendengaran, penciuman, rasa dan raba. Suami dan keluarga dapat memberikan dukungan moril dan materil kepada ibu. Hasil penelitian Liamputtong dimana suami merupakan hal yang sangat penting untuk memperkuat proses penerimaan individu terhadap perubahan yang dialaminya dan Joko Sutrisno, 1997 dalam penelitiannya yang menemukan bahwa suami, orang tua dan mertua adalah anggota keluarga yang referensi yang paling sering memberikan anjuran memilih tenaga penolong persalinan. Penelitian Semenic et al menunjukkan bahwa dukungan suami berpengaruh terhadap pemberian ASI eksklusif (7,11\%). Berdasarkan hasil penelitian Kirana bahwa hubungan antara dukungan suami/keluarga terhadap pemberian ASI eksklusif sesuai penelitian adalah $\mathrm{P}$ value $=0,005($ Pvalue $<\alpha)$ maka dapat disimpulkan ada hubungan antara dukungan suami/keluarga terhadap pemberian ASI eksklusif. $^{7}$

Perilaku adalah tindakan atau aktivitas dari manusia itu sendiri yang mempunyai bentangan yang sangat luas antara lain berjalan, berbicara, menangis, tertawa, bekerja, kuliah, menulis, membaca, dan sebagainya. Dari uraian ini dapat disimpulkan bahwa yang dimaksud perilaku manusia adalah semua kegiatan atau aktivitas manusia, baik yang diamati langsung, maupun yang tidak dapat diamati oleh pihak luar. Menurut Skinner, seperti yang dikutip oleh Notoatmodjo (2003), merumuskan bahwa perilaku merupakan respon atau reaksi seseorang terhadap stimulus atau rangsangan dari luar. Oleh karena perilaku ini terjadi melalui proses adanya stimulus terhadap organisme, dan kemudian organisme tersebut merespons, maka teori Skinner ini disebut teori "S-O-R" atau Stimulus Organisme - Respon. ${ }^{8}$

Berdasarkan data di rumah sakit Hermina Bekasi, jumlah ibu menyusui yang berkunjung ke klinik laktasi periode Januari-Desember tahun 2014 hanya sebanyak 550 orang dengan rata-rata perbulannya 33-45 orang. Angka ini masih jauh dari target pencapaian kunjungan untuk kedepannya menyukseskan program ASI eksklusif.
Berdasarkan rumusan masalah diatas maka belum diketahuinya Pengaruh Dukungan Suami, Pengetahuan Dan Sikap Ibu Terhadap Perilaku Ibu menyusui dalam melakukan kunjungan ke klinik laktasi Rumah Sakit Hermina Bekasi Tahun 2015.

Tujuan penelitian ini adalah Mengetahui pengaruh langsung dan tidak langsung serta besaran Dukungan Suami, Pengetahuan dan Sikap Ibu Terhadap Perilaku Ibu menyusui dalam melakukan kunjungan ke klinik laktasi Rumah Sakit Hermina Bekasi Tahun 2015.

\section{Metode}

Desain Penelitian ini menggunakan cross sectional. Survey cross sectional ialah suatu penelitian untuk mempelajari dinamika korelasi antara faktor-faktor resiko dengan efek, dengan cara pendekatan, observasi atau pengumpulan data sekaligus pada suatu saat (point time approach). Artinya, tiap subjek penelitian hanya diobservasi sekali saja dan pengukuran dilakukan terhadap status karakter atau variabel subjek pada saat pemeriksaan. Hal ini tidak berarti bahwa semua subjek penelitian diamati pada waktu yang sama. Desain ini dapat mengetahui dengan jelas mana yang jadi pemajan dan outcome, serta jelas kaitannya hubungan sebab akibatnya. ${ }^{15}$

Wilayah penelitian yang menjadi data primer adalah Rumah Sakit Hermina Bekasi. Waktu penelitian ini adalah bulan Maret 2015 selama 3 hari.

Populasi adalah keseluruhan objek penelitian atau objek yang diteliti. Populasi target dan studi pada penelitian ini adalah seluruh ibu menyusui yang datang berkunjung ke klinik laktasi Rumah Sakit Hermina Bekasi pada bulan Maret 2015. Besar sampel dalam penelitian ini terdiri dari accidental sampling yaitu seluruh ibu menyusui yang pernah berkunjung ke klinik laktasi Rumah Sakit Hermina Bekasi sebanyak 45 orang dengan kriteria dapat menjawab sendiri kuesioner dan memenuhi kriteria bahwa responden tersebut mampu berkomunikasi dengan baik dalam memberikan informasi yang dibutuhkan. Kriteria inklusi pada penelitian ini adalah semua Ibu menyusui yang berkunjung ke klinik laktasi Rumah Sakit Hermina Bekasi dan mau jadi responden penelitian.

Kriteria eksklusi adalah ibu yang menolak menjadi responden penelitian. Jumlah sample 
diambil sesuai dengan kaidah jumlah sample pada pedoman PLS (Partial Least Square) dimana besaran sample (sample size) yang diambil adalah 5 hingga 10 kelipatan dari jumlah indikator yang akan diteliti. Penentuan sampel yang representatif menurut Hair et al dalam Ghozali (2011) adalah jumlah indikator dikalikan 5-10, adapun jumlah indikator yang digunakan dalam penelitian ini adalah 9 maka ukuran sampelnya berada pada rentang 45-90 responden. ${ }^{16}$ Jadi sampel pada penelitian ini dibulatkan menjadi 45. Data penelitian diambil dari data primer dengan tekhnik mengisi kuesioner. Pengumpulan data pada ibu menyusui meliputi latar belakang responden, pengetahuan, sikap dan dukungan suami terhadap perilaku ibu menyusui dalam melakukan kunjungan ke klinik laktasi Rumah Sakit Hermina Bekasi pada bulan Maret 2015.

Metode pengukuran baik untuk variabel eksogen maupun endogen yang digunakan dalam penelitian ini menggunakan skala interval, sedangkan teknik pengukuranya menggunakan semantic differential, yang mempunyai skala 5 point. Pada skala ini sifat positif diberi nilai paling besar dan sifat negative diberi nilai paling kecil, demikian juga prinsip menggabungkan positif-negatif dan negative-positif.

Tekhnik analisis data menggunakan Structural Equation Modelling (SEM) dengan Partial Least Square (PLS), dilakukan untuk menjelaskan secara menyeluruh hubungan antar variabel yang ada dalam penelitian. SEM digunakan bukan untuk merancang suatu teori, tetapi lebih ditujukan untuk memeriksa dan membenarkan suatu model. Oleh karena itu, syarat utama menggunakan SEM adalah membangun suatu model hipotesis yang terdiri dari model structural dan model pengukuran dalam bentuk diagram jalur yang berdasarkan justifikasi teori. Data yang sudah terkumpul, kemudian dilakukan beberapa tahap pengolahan data, yaitu: editing, coding, processing dan cleaning.

\section{Hasil}

Dalam penelitian ini mencakup 45 responden yaitu ibu menyusui dalam melakukan kunjungan ke klinik laktasi Rumah Sakit Hermina Bekasi Tahun 2015. Variabel yang diukur dalam penelitian ini adalah variabel pengetahuan, dukungan suami, sikap dan perilaku.

\section{Model Faktor Loading}

Hasil faktor loading indikator terhadap masing-masing variabelnya dapat dilihat pada gambar di bawah ini. Berikut output hasil run awal:

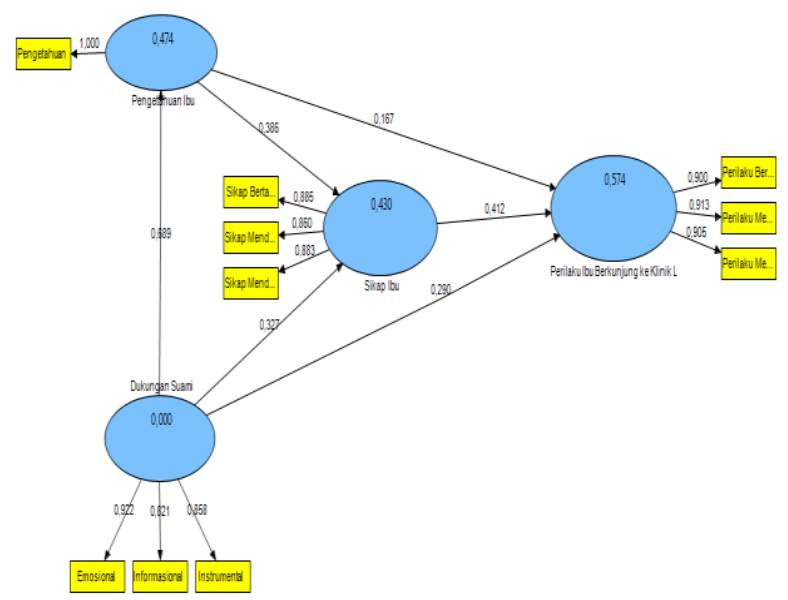

\section{Gambar 1 \\ Output PLS (Loading Factors)}

\section{Cross Loading}

Tujuan cross loading adalah untuk mengetahui apakah variabel mampu memprediksi lebih tinggi faktor loading indikatornya dibandingkan prediksi terhadap indikator lainnya dengan melihat nilai cross loading. Selain itu, untuk melihat validitas indikator yang digunakan dalam penelitian dapat dilakukan dengan mengevaluasi hasil cross loading semua indikator.

Suatu indikator dinyatakan valid jika mempunyai loading factor tertinggi kepada konstruk yang dituju dibandingkan loading factor kepada konstruk lain. Berdasarkan tabel menunjukkan bahwa korelasi konstruk lebih besar dari pada ukuran konstruk lainnya. Hal itu menunjukkan bahwa konstruk laten memprediksi ukuran pada bloknya lebih baik dari pada ukuran pada blok lainnya.

\section{Outer Loading (Convergent Validity)}

Suatu indikator reflektif dinyatakan valid jika mempunyai loading factor di atas 0,5 terhadap konstruk yang dituju berdasarkan pada substantive content-nya dengan melihat signifikansi dari weight $(\mathrm{t}=1,96)$.

\section{Discriminant Validity dari Akar AVE}

Cara untuk melihat discriminant validity dengan melihat nilai square root of average variance extracted (AVE). Nilai yang diharapkan di atas 0,50. Metode lain untuk 
menilai discriminant validity adalah membandingkan nilai square root of average variance extracted (AVE) setiap konstruk dengan nilai akar kuadrat AVE. Jika nilai akar kuadrat AVE setiap konstruk lebih besar dari nilai square root of average variance extracted (AVE) setiap konstruk dalam model, maka dikatakan memiliki nilai discriminant validity yang.

\section{Cronbach's Alpha dan Composite Reliability}

Setelah diuji validitas dan dinyatakan variabel dan indikator telah valid, maka dilakukan uji reliabilitas Hasil evaluasi reliabilitas outer model diatur dalam tabel di bawah ini dengan mengevaluasi nilai Cronbach's Alpha dan Composite Reliability.

\section{Evaluasi Inner Model}

\section{Model Faktor Loading}

Hasil evaluasi signifikan outer model diatur dalam output PLS di bawah ini dengan mengevaluasi refleksi nilai $T$-statistic indikator terhadap variabelnya. Evaluasi signifikansi outer model dilakukan untuk menilai signifikansi konstruk laten dengan konstruknya, yaitu dengan membandingkan nilai $\mathrm{t}$ statistik masing-masing konstruk laten dengan nilai $\alpha=0,05(1,96)$. Untuk mengukur nilai $\mathrm{t}$ statistik dilakukan bootstrapping pada model dengan hasil sebagai berikut:

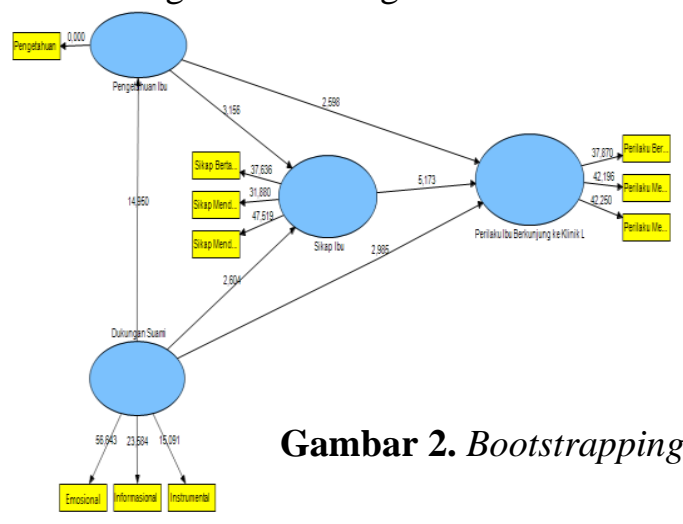

Setelah dilakukan bootstrapping untuk mengukur nilai t statistik dari masing-masing konstruk laten terhadap konstruknya, maka nilai $\mathrm{t}$ statistik dibandingkan dengan nilai $\alpha=$ $0,05(1,96)$. Ketentuannya, apabila nilai $\quad \mathrm{t}$ statistik lebih besar dari nilai $\alpha=0,05(1,96)$, maka konstruk laten tersebut signifikan terhadap konstruknya. Inner model disebut juga dengan nilai $R$ Square, uji hipotesis TStatistik, pengaruh variabel langsung dan prediktif (nilai $Q$ Square).

\section{Nilai $R$ Square}

Nilai square berfungsi untuk menilai besaran keragaman atau variasi data penelitian terhadap fenomena yang sedang dikaji. Pengujian terhadap model struktural dilakukan dengan melihat nilai $R$-Square yang merupakan uji goodness-fit model. Uji yang kedua adalah melihat signifikansi pengaruh antar konstruk (Ghozali, 2011). Berikut ini adalah hasil pengukuran nilai $R$-Square, yang juga merupakan nilai goodness of fit model. Berikut hasil output-nya dalam bentuk tabel 1 .

Berdasarkan tabel 1 dukungan suami berkontribusi terhadap pengetahuan sebesar 0,474 , dukungan suami, dan pengetahuan berkontribusi terhadap sikap sebesar 0,430, dan dukungan suami, sikap, serta pengetahuan berkontribusi terhadap perilaku sebesar 0,574. Berdasarkan hasil pengukuran tersebut dapat disimpulkan bahwa variabilitas konstruk pengetahuan mampu dijelaskan oleh variabilitas dukungan suami sebesar $47,4 \%$ dan $52,6 \%$ dijelaskan oleh variable lain yang tidak diteliti. Variabilitas konstruk sikap mampu dijelaskan oleh variabilitas dukungan suami, dan pengetahuan sebesar 43,0\% dan $57,0 \%$ dijelaskan oleh variabel lain yang tidak diteliti. Sedangkan variabilitas konstruk perilaku mampu dijelaskan oleh variabilitas dukungan suami, sikap, serta pengetahuan sebesar 57,4\% dan 42,6\% dijelaskan oleh variabel lain yang tidak diteliti.

Tabel 1. Hasil Pengukuran $R$-Square dari Variabel Pengetahuan, Dukungan Suami, Sikap, dan Perilaku Ibu Menyusui di Klinik Laktasi Rumah Sakit Hermina Bekasi Tahun 2015

\begin{tabular}{lcc}
\hline & Variabel & R Square \\
\hline Dukungan Suami & \\
\hline Pengetahuan Ibu & 0,474 \\
\hline Perilaku Ibu Berkunjung & 0,574 \\
\hline Sikap Ibu & 0,430 \\
\hline Sum
\end{tabular}

Sumber : Smart PLS 2.0 report, 2015 


\section{Uji Hipotesis T Statistik}

Untuk melihat uji hipotesis terhadap indikator dari variabel yang diteliti, dapat dilihat melalui tabel berikut ini:

Tabel 2. Evaluasi Refleksi Nilai T-Statistik terhadap Indikator dari Variabel Pengetahuan, Dukungan Suami, Sikap, dan Perilaku Ibu Menyusui di Klinik Laktasi Rumah Sakit Hermina Bekasi Tahun 2015

\begin{tabular}{|c|c|c|c|c|}
\hline Hubungan Antar Variabel & $\begin{array}{c}\text { Original Sampel } \\
(\text { Rho })\end{array}$ & $\begin{array}{l}\text { Nilai T } \\
(>1,96)\end{array}$ & $\mathbf{H}_{\mathbf{o}}$ & Kesimpulan \\
\hline $\begin{array}{l}\text { Dukungan Suami } \rightarrow \\
\text { Pengetahuan Ibu }\end{array}$ & 0,689 & 14,950 & Ditolak & $\begin{array}{c}\text { Berpengaruh } \\
\text { Positif dan } \\
\text { Signifikan }\end{array}$ \\
\hline $\begin{array}{l}\text { Dukungan Suami } \rightarrow \text { Perilaku } \\
\text { Ibu Berkunjung }\end{array}$ & 0,290 & 2,985 & Ditolak & $\begin{array}{c}\text { Berpengaruh } \\
\text { Positif dan } \\
\text { Signifikan }\end{array}$ \\
\hline $\begin{array}{l}\text { Dukungan Suami } \rightarrow \\
\text { Sikap Ibu }\end{array}$ & 0,327 & 2,604 & Ditolak & $\begin{array}{c}\text { Berpengaruh } \\
\text { Positif dan } \\
\text { Signifikan }\end{array}$ \\
\hline $\begin{array}{l}\text { Pengetahuan Ibu } \rightarrow \text { Perilaku Ibu } \\
\text { Berkunjung }\end{array}$ & 0,167 & 2,598 & Ditolak & $\begin{array}{c}\text { Berpengaruh } \\
\text { Positif dan } \\
\text { Signifikan }\end{array}$ \\
\hline $\begin{array}{l}\text { Pengetahuan Ibu } \rightarrow \\
\text { Sikap Ibu }\end{array}$ & 0,386 & 3,156 & Ditolak & $\begin{array}{c}\text { Berpengaruh } \\
\text { Positif dan } \\
\text { Signifikan }\end{array}$ \\
\hline
\end{tabular}

Sumber : Smart PLS 2.0 report, 2015

\section{Nilai Direct dan Indirect}

Setelah diketahui $R$-Square dan Path Coeficient, selanjutnya dilakukan pengukuran untuk mengetahui besaran pengaruh langsung dan tidak langsung antar variabel dengan hasil sebagai berikut:

Tabel 3. Persentase Pengaruh Antar Variabel Terhadap Konstruk Variabel Perilaku pada Model di Klinik Laktasi Rumah Sakit Hermina Bekasi Tahun 2015

\begin{tabular}{lccccccc}
\hline Sumber & $\begin{array}{c}\boldsymbol{L} \boldsymbol{V} \\
\text { Correlati } \\
\text { on }\end{array}$ & Direct Rho & $\begin{array}{c}\text { Inderect } \\
\boldsymbol{R h o}\end{array}$ & Total & $\begin{array}{c}\text { Direct } \\
\boldsymbol{\%}\end{array}$ & $\begin{array}{c}\text { Indirect } \\
\boldsymbol{\%}\end{array}$ & $\begin{array}{c}\text { Total } \\
\boldsymbol{\%}\end{array}$ \\
\hline Pengetahuan & 0,618 & 0,167 & 0,080 & 0,247 & 10,32 & 3,33 & 13,65 \\
Dukungan Suami & 0,649 & 0,290 & 0,004 & 0,294 & 18,82 & 6,68 & 25,50 \\
Sikap & 0,686 & 0,412 & 0 & 0,412 & 28,26 & 0 & 28,26 \\
\hline Total & $\mathbf{5 7 , 4 0}$ & $\mathbf{1 0 , 0 2}$ & $\mathbf{6 7 , 4 2}$ & & & & \\
\hline
\end{tabular}


Dari tabel 3 menyatakan bahwa pengetahuan berpengaruh secara langsung dan tidak langsung terhadap perilaku. Hasil uji koefisien parameter antara pengetahuan terhadap perilaku menunjukkan terdapat pengaruh langsung sebesar $10,32 \%$, sedangkan untuk pengaruh tidak langsung antara sikap terhadap perilaku melalui pengetahuan didapat dengan mengalikan koefisien jalur (pengetahuan $\rightarrow$ sikap) x LV (pengetahuan $\rightarrow$ sikap) dengan koefisien jalur (sikap $\rightarrow$ perilaku) x LV (sikap $\rightarrow$ perilaku) sehingga mendapat nilai sebesar 3,33\%.

Dukungan suami berpengaruh secara langsung dan tidak langsung terhadap perilaku. Hasil uji koefisien parameter antara dukungan suami terhadap perilaku menunjukkan terdapat pengaruh langsung sebesar $18,82 \%$, sedangkan untuk pengaruh tidak langsung dengan mengalikan koefisien jalur antara (dukungan suami terhadap perilaku melalui pengetahuan) dengan (dukungan suami terhadap perilaku melalui sikap) didapat (dukungan suami $\rightarrow$ pengetahuan) $\mathrm{x}$ LV (dukungan suami $\rightarrow$ pengetahuan) dengan koefisien jalur (pengetahuan $\rightarrow$ perilaku) x LV (pengetahuan $\rightarrow$ perilaku)\} dikalikan

dengan \{(dukungan suami $\rightarrow$ sikap) x LV (dukungan suami $\rightarrow$ sikap) dengan koefisien jalur (sikap $\rightarrow$ perilaku) x LV (sikap $\rightarrow$ perilaku)\} sehingga mendapat nilai sebesar $6,68 \%$.

Dari tabel 3 menyatakan bahwa sikap berpengaruh secara langsung terhadap perilaku. Hasil uji koefisien parameter antara sikap terhadap perilaku menunjukkan terdapat pengaruh langsung sebesar $28,26 \%$. Sehingga nilai dari masing-masing pengaruh langsung variabel laten independen tersebut apabila secara bersama-sama menunjukkan kesesuaian dengan nilai $R$ Square atau dengan kata lain hal ini menyatakan bahwa variabel dukungan suami, pengetahuan, dan sikap mampu menjelaskan variabel perilaku sebesar $(10,32+$ $18,82+28,26)=57,40$.

\section{Persamaan Matematis}

Secara matematis, bentuk persamaan struktural dari model penelitian ini adalah sebagai berikut:

$$
\begin{gathered}
\mathbf{Y}=\gamma_{5} . \xi_{1}+\zeta_{1} \\
\text { Pengetahuan }=0,689 \times \text { Dukungan Suami }+ \\
\boldsymbol{\eta}_{1}=\gamma_{3} . \mathbf{X}+\gamma_{4} . \xi_{1}+\zeta_{2}
\end{gathered}
$$

$$
\begin{aligned}
& \text { Sikap }=0,386 \text { x Pengetahuan }+0,327 \mathrm{x} \\
& \text { Dukungan Suami }+0,570 \\
& \boldsymbol{\eta}_{\mathbf{2}}=\boldsymbol{\gamma}_{\mathbf{1}} \cdot \mathbf{X}+\boldsymbol{\gamma}_{\mathbf{2}} \cdot \boldsymbol{\xi}_{\mathbf{1}}+ \\
& \boldsymbol{\beta}_{\mathbf{1}} \cdot \boldsymbol{\eta}_{\mathbf{1}}+\boldsymbol{\zeta}_{3}
\end{aligned}
$$

Perilaku $=0,167 \times$ Pengatahuan $+0,290 \times$ Dukungan

$$
\text { Suami + 0,412 x Sikap + 0,426 }
$$

Perilaku Ibu Menyusui dalam melakukan kunjungan ke Klinik Laktasi Rumah Sakit Hermina Bekasi Tahun 2015 dipengaruhi oleh pengetahuan sebesar 0,167 , dukungan suami sebesar 0,290, dipengaruhi oleh sikap sebesar 0,412, dan dipengaruhi oleh faktor lain sebesar 0,426 artinya terdapat pengaruh yang positif dari dukungan suami, sikap, dan pengetahuan, semakin tinggi dukungan suami, dan semakin positif sikap, serta semakin tinggi pengetahuan maka akan semakin meningkat pula perilaku Ibu Menyusui dalam melakukan kunjungan ke Klinik Laktasi Rumah Sakit Hermina Bekasi Tahun 2015.

\section{Predictive Relevance (Nilai Q-Square)}

Uji $Q$-Square $\left(Q^{2}\right)$ bertujuan untuk menilai besaran keragaman data atau variasi data penelitian terhadap fenomena yang sedang diteliti. Formula yang digunakan untuk mengukur $Q$-Square $\left(Q^{2}\right)$ adalah sebagai berikut:

$$
\begin{aligned}
Q^{2} & =1-\left(1-\mathrm{R}_{1}{ }^{2}\right)\left(1-\mathrm{R}_{2}{ }^{2}\right)\left(1-\mathrm{R}_{3}{ }^{2}\right) \\
Q^{2} & =1-(1-0,474)(1-0,430)(1-0,574) \\
Q^{2} & =0,8723 \Rightarrow 87,23 \%
\end{aligned}
$$

Berdasarkan hasil perhitungan tersebut dapat disimpulkan bahwa model mampu menjelaskan variabilitas data sebesar $87,23 \%$, sedangkan $12,77 \%$ dijelaskan oleh variabel lain yang tidak dikaji dalam

\section{Pembahasan \\ Pengaruh langsung Dukungan Suami Terhadap Perilaku ibu menyusui dalam melakukan kunjungan ke klinik laktasi}

Indikator pada variabel dukungan suami yang digunakan pada penelitian ini sebanyak 3 indikator yaitu (1) informasional, (2) instrumental, (3) emosional. Adapun indikator dari variabel perilaku ibu menyusui dalam melakukan kunjungan ke klinik laktasi adalah (1) mendapatkan pengobatan, (2) bertanggung jawab, (3) mendapatkan informasi.

Dari hasil penelitian, model pengaruh langsung dukungan suami terhadap perilaku ibu menyusui dalam melakukan kunjungan ke klinik laktasi memberikan nilai t statistik 2,985 
yang berarti ada pengaruh antara dukungan suami terhadap perilaku.

Pilihan seseorang dalam memanfaatkan pelayanan kesehatan dipengaruhi oleh pendapat orang lain. Umumnya kerabat dekat atau teman dijadikan sumber informasi pertama sebelum seseorang memanfaatkan jasa pelayanan kesehatan tertentu. Status ibu dalam masyarakat banyak dipengaruhi oleh faktor sosial budaya, dimana pada umumnya dengan tingkat pendidikan rendah mereka memiliki keterbatasan otonomi antara lain sub-ordinasi terhadap suami, mertua, anggota keluarga lainnya, sehingga tanpa ijin dari pihak lain diluar dirinya sangat sulit bagi ibu untuk mendapatkan pelayanan kesehatan meskipun sedang menghadapi resiko kematian.

Menurut hasil penelitian Hasbiah (2004), ada hubungan yang bermakna antara dukungan suami terhadap perilaku dengan nilai $\mathrm{p}=0,000$ dan $\mathrm{OR}=15,167$. Hasil analisis multivariat dengan uji regresi logistik menunjukkan bahwa dukungan suami mempunyai hubungan yang dominan terhadap perilaku dengan nilai $\mathrm{p}=$ $0,003 \cdot{ }^{17}$

Penulis berasumsi bahwa adanya pengaruh antara dukungan suami dengan perilaku ibu karena suami adalah orang terdekat ibu yang referensi dan paling sering memberikan anjuran memilih pelayanan kesehatan yang dibutuhkan dalam hal ini perilaku ibu berkunjung didasari dari dukungan suami. Dapat memberikan dukungan moril dan materil kepada ibu.

\section{Pengaruh langsung Dukungan Suami Terhadap sikap ibu dalam Perilaku ibu menyusui dalam melakukan kunjungan ke klinik laktasi}

Dari hasil penelitian, model pengaruh langsung dukungan suami terhadap sikap ibu dalam perilaku ibu menyusui dalam melakukan kunjungan ke klinik laktasi memberikan nilai $\mathrm{t}$ statistik 2,604 yang artinya ada pengaruh dukungan suami terhadap sikap ibu.

Dukungan keluarga adalah sikap, tindakan dan penerimaan keluarga terhadap anggotanya. Anggota keluarga memandang bahwa orang yang bersifat mendukung selalu siap memberikan pertolongan dan bantuan jika diperlukan (Friedman, 1998). Pada hakekatnya keluarga diharapkan mampu berfungsi untuk mewujudkan proses pengembangan timbal balik rasa cinta dan kasih sayang antara anggota keluarga, antar kerabat, serta antar generasi yang merupakan dasar keluarga yang harmonis.

Hasil penelitian Hargi (2013) menyebutkan bahwa ada hubungan antara dukungan suami terhadap sikap ibu. Peneliti berasumsi bahwa faktor pembentuk dan pengubah sikap bisa berasal dari teman, keluarga (suami), lingkungan dan media sehingga dukungan suami yang diperoleh seorang ibu dapat menjadikan faktor dari sikap ibu dalam berkunjung ke klinik laktasi. ${ }^{18}$

\section{Pengaruh langsung Dukungan Suami Terhadap pengetahuan ibu dalam Perilaku ibu menyusui dalam melakukan kunjungan ke klinik laktasi}

Dari hasil penelitian, model pengaruh langsung dukungan suami terhadap pengetahuan ibu dalam perilaku ibu menyusui dalam melakukan kunjungan ke klinik laktasi memberikan nilai $t$ statistik 14,950 yang artinya ada pengaruh dukungan suami terhadap pengetahuan ibu.

Dukungan sosial keluarga adalah sebuah proses yang terjadi sepanjang masa kehidupan, sifat dan jenis dukungan sosial berbeda-beda dalam berbagai tahap-tahap siklus kehidupan. Namun demikian, dalam semua tahap siklus kehidupan, dukungan sosial keluarga membuat keluarga mampu berfungsi dengan berbagai kepandaian dan akal. Sebagai akibatnya, hal ini meningkatkan kesehatan dan adaptasi keluarga.

Hasil penelitian ini sejalan dengan hasil penelitian Cahyani, dimana peran keluarga dalam hal ini suami berpengaruh terhadap pengetahuan ibu dengan efek 0,271 dan $\mathrm{P}=$ 0,005 . Peneliti berasumsi bahwa adanya pengaruh dukungan suami terhadap pengetahuan ibu karena suami adalah orang terdekat ibu dalam keluarga yang memberikan dukungan instrumental, emosional termasuk juga informasional yang dapat mempengaruhi pengetahuan ibu. ${ }^{19}$

\footnotetext{
Pengaruh langsung Pengetahuan Ibu terhadap Perilaku ibu menyusui dalam melakukan kunjungan ke klinik laktasi

Dari hasil penelitian, model pengaruh langsung pengetahuan Ibu terhadap perilaku ibu menyusui dalam melakukan kunjungan ke klinik laktasi memberikan nilai t statistik 2,598 yang artinya pengetahuan ibu berpengaruh terhadap perilaku ibu.
} 
Pengertian pengetahuan merupakan hasil dari tahu, dan ini terjadi setelah seseorang melakukan pengindraan terhadap suatu objek tertentu, yakni indra penglihatan, pendengaran, penciuman, rasa dan raba. Sebagian besar pengetahuan manusia diperoleh melalui mata dan telinga. Pengetahuan/kognitif merupakan domain yang sangat penting dalam membentuk tindakan seseorang.. Menurut Sarwono (1997), perilaku manusia merupakan hasil dari segala macam pengalaman serta interaksi manusia dengan lingkungannya yang terwujud dalam bentuk pengetahuan, sikap dan tindakan.

Dengan kata lain, perilaku merupakan respon atau reaksi individu terhadap stimulasi yang berasal dari luar maupun dari dalam dirinya.

Berdasarkan penelitian Bidaya (2013), bahwa dari hasil uji chi square terdapat hubungan antara tingkat pengetahuan dengan perilaku dengan $\mathrm{p}$ value $=0,00$. Hasil penelitian Hasbiah (2004) didapatkan hasil uji Fisher exact nilai $\mathrm{p}=0,012$ yang artinya ada hubungan yang bermakna antara pengetahuan dengan perilaku. Peneliti berasumsi bahwa adanya pengaruh langsung pengetahuan ibu terhadap perilaku didasari karena pengetahuan/kognitif merupakan domain yang sangat penting dalam membentuk tindakan seseorang. Manusia adalah makhluk rasional, tingkah lakunya ditentukan oleh kemampuan berfikir. Semakin berpendidikan dan berpengetahuan maka akan semakin sadar melakukan perbuatan untuk memenuhi kebutuhan. Dalam hal ini, ibu yang datang berkunjung ke klinik laktasi didasari oleh karena kebutuhannya untuk mendapatkan informasi dan pengobatan. ${ }^{20}$

\section{Pengaruh langsung sikap ibu terhadap Perilaku ibu menyusui dalam melakukan kunjungan ke klinik laktasi}

Indikator pada variabel sikap ibu yang digunakan pada penelitian ini sebanyak 3 indikator yaitu (1) mendapatkan pengobatan, (2) bertanggung jawab, (3) mendapatkan informasi. Adapun indikator dari variabel perilaku ibu menyusui dalam melakukan kunjungan ke klinik laktasi adalah (1) mendapatkan pengobatan, (2) bertanggung jawab, (3) mendapatkan informasi.

Dari hasil penelitian, model pengaruh langsung sikap ibu terhadap perilaku ibu menyusui dalam melakukan kunjungan ke klinik laktasi memberikan nilai t statistik 5,173 yang berarti ada pengaruh antara sikap ibu dengan perilaku ibu.

Sikap adalah suatu pola perilaku, tendensi atau kesepian antisipatif, predisposisi untuk menyesuaikan diri dalam situasi sosial, atau secara sederhana, sikap adalah respon terhadap stimuli sosial yang telah terkondisikan.

Hasil penelitian serupa didapatkan hasil ada hubungan antara sikap dengan perilaku ibu dengan $\mathrm{p}$ value $=0.04$. Peneliti berasumsi bahwa adanya pengaruh langsung sikap ibu terhadap perilaku karena sikap sebagai kesediaan untuk bereaksi (disposition to react) secara positif (favorably) atau secara negative (unfavorably) terhadap objek-objek tertentu. Sebagai suatu pola perilaku, tendensi atau kesepian antisipatif, predisposisi untuk menyesuaikan diri dalam situasi sosial, atau secara sederhana, sikap adalah respon terhadap stimuli sosial yang telah terkondisikan. Dalam hal ini adalah pola perilaku ibu menyusui yang berkunjung ke klinik laktasi dimana ibu mempunyai sikap (respon tertutup) dan dilakukan dalam bentuk perilaku. ${ }^{21}$

\section{Pengaruh langsung Pengetahuan Ibu terhadap Sikap ibu dalam Perilaku ibu menyusui dalam melakukan kunjungan ke klinik laktasi}

Dari hasil penelitian, model pengaruh langsung pengetahuan ibu terhadap sikap ibu dalam perilaku ibu menyusui dalam melakukan kunjungan ke klinik laktasi memberikan nilai $\mathrm{t}$ statistik 3,156 yang artinya ada pengaruh pengetahuan dengan sikap ibu.

Menurut Sarnoff (dalam Sarwono, 2000) mengidentifikasikan sikap sebagai kesediaan untuk bereaksi (disposition to react) secara positif (favorably) atau secara negative (unfavorably) terhadap objek-objek tertentu. D. Krech dan R.S Crutchfield (dalam Sears, 1999) berpendapat bahwa sikap sebagai organisasi yang bersikap menetap dari proses motivational, emosional, perseptual, dan kognitif mengenai aspek dunia individu.

Hasil penelitian ini sejalan dengan hasil penelitian dimana pengetahuan ibu berpengaruh terhadap sikap ibu dengan efek 0,362 dan $\mathrm{P}=0,00$. Hasil penelitian Purnama (2008), didapatkan sikap signifikan dipengaruhi oleh pendidikan dan pengetahuan ibu dimana nilai $t$ statistic

1,96. Peneliti berasumsi bahwa adanya pengaruh antara pengetahuan dan sikap ibu karena pengetahuan yang tinggi akan 
mempengaruhi sikap ibu untuk berkunjung ke klinik laktasi.

\section{Kesimpulan}

Berdasarkan hasil penelitian ini, maka didapatkan temuan sebagai berikut : 5 hubungan antar variabel berpengaruh signifikan secara positif dengan taraf $\alpha=5 \%$ $(0,05=$ confidence $95 \%)$ dari sampel 45 orang pada model akhir yang dimodifikasi. Terbentuk 3 variabel (pengetahuan, dukungan suami, dan sikap) yang memiliki pengaruh secara langsung dengan goodness of fit yang signifikan terhadap variabel perilaku. Variabel sikap merupakan variabel yang paling berpengaruh positif, dengan $\mathrm{T}_{\text {hitung }}$ sebesar 3,156 di atas nilai $T_{\text {tabel }}(1,96)$. Persentase pengaruh semua variabel terhadap perilaku dalam model ini sebesar $67,42 \%$, yang terdiri dari pengaruh langsung sebesar $57,40 \%$ dan pengaruh tidak langsung sebesar $10,02 \%$. Nilai $Q$ Square (predictive relevance), bahwa model mampu menjelaskan variabilitas data sebesar $87,23 \%$, sedangkan $12,77 \%$ dijelaskan oleh variabel lain yang tidak dikaji dalam penelitian ini.

Dengan demikian, berdasarkan temuan tersebut dapat disimpulkan bahwa variabel perilaku dipengaruhi oleh pengetahuan, dukungan suami, dan sikap secara stimultan sebesar 67,42\%, sedangkan 32,58\% dipengaruhi oleh variabel lain yang tidak diteliti dalam penelitian ini. Selain itu, dapat ditarik kesimpulan bahwa variabel perilaku Ibu Menyusui dalam melakukan kunjungan ke Klinik Laktasi Rumah Sakit Hermina Bekasi sebesar 28,26\% lebih besar dipengaruhi oleh sikap dibandingkan variabel yang lain. Sikap perlu mendapat perhatian yang besar bagi Ibu Menyusui dalam melakukan kunjungan ke Klinik Laktasi Rumah Sakit Hermina Bekasi.

\section{Saran}

Dari hasil penelitian ini serta berdasarkan keterbatasan penelitian, maka beberapa saran yang dapat diberikan peneliti antara lain: Diharapkan Rumah Sakit Hermina Bekasi untuk lebih mempromosikan klinik laktasinya agar ibu yang berkunjung semakin banyak. Dimana dilakukan pada saat ibu masih hamil sehingga dengan meningkatkan pengetahuan ibu diharapkan dapat merubah sikap ibu menjadi semakin positif. Diharapkan untuk peneliti selanjutnya untuk meneliti lebih dalam dan memakai responden yang lebih banyak.

\section{Daftar Pustaka}

1. Saragih. Skripsi. USU. Medan: 2011.

2. SDKI. 2010. Survei Demografi Kesehatan Indonesia. Infant Mortality Rate: 2010.

3. Maharani D. http://health.kompas.com up date 12 Desember 2015.

4. Kementrian Kesehatan RI. Program pemberian air susu ibu (ASI) secara eksklusif: 2004.

5. Puskesmas Cimaung. Standar Pelayanan Minimal: cakupan klinik/pojok laktasi; 2013.

6. Http;//www.indonesia.go.id/en/index.php/option =com, Angka Kematian Ibu di Indonesia tertinggi di Asia, up date 12 Desember 2014.

7. Notoatmodjo S. Promosi Kesehatan dan Perilaku Kesehatan. Jakarta : PT. Rineka Cipta; 2003.

8. Notoatmodjo S. Ilmu Kesehatan Masyarakat. Jakarta: PT. Rineka Cipta; 2003.

9. Rumah Sakit Hermina. 2014. Profil Rumah Sakit. Jakarta. diakses tanggal 3 Maret 2015.

10. Notoatmodjo S. Metode Penelitian. Jakarta : PT. Rineka Cipta; 2002.

11. Ghozali I. Structural Equating Modeling Metode Alternatif Partial Least Square (PLS). Semarang: Undip; 2012.

12. Hasbiah M. Faktor-Faktor yang Berhubungan dengan Perilaku Pemeriksaan Pap Smear oleh Pegawai Negeri Sipil Wanita di Poltekes Palembang. Universitas Indonesia; 2004.

13. Hargi JP. Hubungan Dukungan Suami dengan Sikap Ibu dalam Pemberian ASI Eksklusif di Wilayah Kerja Puskesmas Arjasa Kabupaten Jember. Universitas Jember; 2013.

14. Cahyani NWW. Penerapan Analisis Jalur dalam Analisis Faktor Determinan Eksklusivitas Pemberian ASI di Wilayah Kerja Puskesmas Payangan, Gianyar. Universitas Udayana; 2014.

15. Bidaya DY. Hubungan Tingkat Pengetahuan Ibu dengan Perilaku Pencegahan ISPA pada Bayi di Puskesmas Kecamatan Segedong. Universitas Tanjung Pura. Pontianak; 2013.

16. Rakhmawati NZ. Hubungan Pengetahuan dan Sikap Idu dengan Perilaku ibu dalam Pemberian Makanan Anak Usia 12-24 bulan. Universitas Diponegoro; 2014. 